Bridgwater, D., Sutton, J. \& Watterson, J. S. 1966: The Precambrian rapakivi suite and surrounding gneisses of the Kap Farvel area, South Greenland. Rapp. Grønlands geol. Unders. 11, 52-54.

Dawes, P. R 1970: The plutonic history of the Tasiussaq area, South Greenland, with special reference to a high-grade gneiss complex. Bull. Grønlands geol. Unders. 88 (also Meddr Grønland 189, 3), 125 pp.

Escher, A. 1966: The deformation and granitisation of Ketilidian rocks in the Nanortalik area, South Greenland. Bull. Grønlands geol Unders. 59 (also Meddr Grønland 172, 9), 102 pp.

Gower, C. F., Flanagan, M. J., Kerr, A. \& Bailey, D. G. 1982: Geology of the Kaipokok Bay-Big River area, Central Mineral Belt, Labrador. Miner. Dev. Div., Dept. Mines Energy, Gov. Newfoundl. Labrador Rep. 82-7, 77 pp.

Langmuir, D. 1978: Uranium solution-mineral equilibra at low temperatures with applications to sedimentary ore deposits. In Kimberley, M. M. (edit.) Short course in uranium deposits: their mineralogy and origin. Toronto: Miner. Ass. Can., 17-55.

Sutton, J. \& Watterson, J. 1968: The flat-lying metamorphic complex and related igneous rocks of Kap Farvel area. Rapp Grønlands geol. Unders. 15, 58-60.

Vorma, A. 1976: On the petrochemistry of rapakivi granites with special reference to the Laitila massif, southwestern Finland. Bull. Comm. geol. Finl. 285, 98 pp.

B. W.,

Elektronisk Afdeling,

Forsфgsanlåg Risф,

DK-4000 Roskilde,

Denmark.

\title{
Uranium exploration in the Qagssiarssuk area, South Greenland
}

\author{
Per Nyegaard
}

Following the promising results of the Syduran project (Armour-Brown et al., 1984) a spin-off project Sydex was initiated in April 1984. The project is financed under the Ministry of Energy's Research Programmes 1984 and field work was carried out in several areas in South Greenland this summer (Armour-Brown \& Wallin, this report). This contribution describes the work in the Qagssiarssuk area (fig. 20). In connection with the prospecting a geophysical survey was also carried out (Thorning \& Boserup, this report).

The main objects of the field work were to prospect the granite and sandstone area west of Qagssiarssuk between Tunugdliarfik and Nordre Sermilik (fig. 25) by ground scintillometry and water sampling. The major fault zones and adjacent areas together with the sandstone/ granite unconformity were investigated especially. Water samples from both lakes and streams were collected to test the usefulness of the method in this very poorly exposed area.

Pitchblende and other uranium mineral occurrences have previously been found in major fault zones in the western part of the area (fig. 25) (Armour-Brown et al., 1983). Radioactive thorium-dominated dykes have also been found (Hansen, 1968; Armour-Brown et al., 1982). Stream-water and sediment samples with anomalously high uranium are located within the prospected area (Armour-Brown et al., 1982). 
Fig. 25. Simplified geological map of the Qagssiarssuk area with uranium occurrences. Triangles: U mineral occurrences found in previous years; circles: U mineral occurrences found in 1984; P: pitchblende showings; A,B,C \& D: localities with references to text.

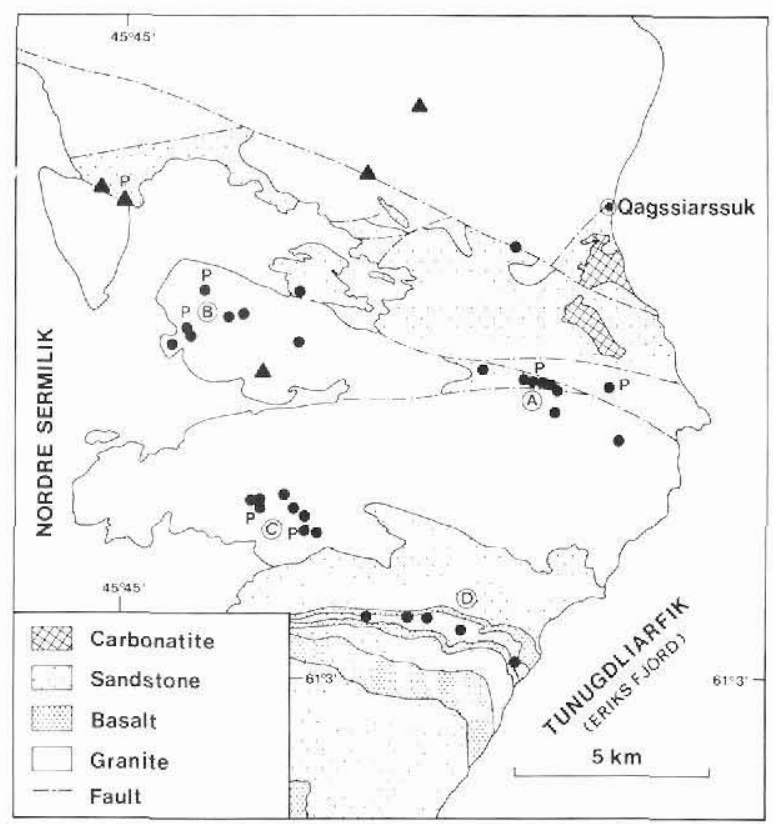

\section{Geology}

The area is composed of late Ketilidian, coarse-grained biotite granite (1782 \pm 20 m.a.; Van Breemen et al., 1974), aplite and bodies of dioritic rocks commonly veined by granitic rocks. The granite was subjected during the Gardar period (1330-1150 Ma; Emeleus \& Upton, 1976) to faulting and deposition of red sandstones and lavas (the Eriksfjord Formation; Poulsen, 1964), to emplacement of a dyke swarm of basic and alkaline dykes, and to carbonate volcanism (Allaart, 1983). The Ketilidian and Gardar rocks are dissected by two main sets of faults trending ENE and E-W. The E-W faults have a total displacement of about 7 $\mathrm{km}$ with a sinistral sense and with a smaller vertical component which has contributed to the preservation of the Eriksfjord Formation (Emeleus \& Stephenson, 1970).

\section{Results}

Prospecting with scintillometers resulted in the finding of several small pitchblende occurrences in both the granite and sandstone. Radioactive uranium or thorium-dominated joints and dykes were also found in the area.

In the sandstone wedge, bordered by two major fault zones in the central part of the area (fig. 25, loc. A), many scattered small pitchblende occurrences were found along a $5 \mathrm{~m}$ high fault-controlled east-west wall. These occurrences were traced for about $1 \mathrm{~km}$ in a $2-3 \mathrm{~m}$ wide zone adjacent to the fault. Pitchblende is found as cavity fillings up to $0.5 \mathrm{~cm}$ wide, but also as smears along tension joints striking $40-60^{\circ}$. Hematite, limonite and secondary uranium minerals are associated with the pitchblende. The sandstone is strongly brecciated and cemented by quartz. 
Several other small uranium mineral occurrences were located in the vicinity of the two faults bordering the sandstone wedge, both in the sandstone and the granite.

In the granite area to the west (fig. 25 , loc. B), which is dissected by many faults and fractures, uranium mineral occurrences were found at several localities. One of these localities has two small pitchblende veins with secondary, yellow, uranium minerals. The veins are lying 'en échelon' and they are traced $1.5-2 \mathrm{~m}$ striking $60^{\circ}$ and are up to $1 \mathrm{~cm}$ wide. Fluorite and hematite are associated with the veins. Pitchblende smears a few millimetres wide are also found at another locality along joints in a fault/dolerite intersection. Secondary uranium minerals, fluorite and hematite are associated with the pitchblende.

In the south-western part of the area (fig. 25 , loc. C), in the granite and in the net-veined diorite, many small localities with uranium mineral occurrences were found along thin joints. Pitchblende was identified at two of these localities. The mineralised joints parallel the $60^{\circ}$ tension direction, but joints striking $90^{\circ}, 115^{\circ}, 130^{\circ}$ and $165^{\circ}$ may have elevated radioactivity. The radioactive joints can be traced up to 3-5 $\mathrm{m}$, and at one locality these joints were rather dense within a $50 \times 10 \mathrm{~m}$ zone.

In the southern part of the area (fig. 25, loc. D), in the Eriksfjord Formation, several localities with uranium mineral occurrences were found in the sandstone just below a sandstone/basalt sill contact. The radioactivity is normally rather weak (75-110 ur, background: 15 ur) and mostly follows the $60^{\circ}$ tension joints. The radioactivity can normally be traced $1-5$ $\mathrm{m}$ along the joints, and at one locality the radioactive joints were scattered within an area of $250 \times 10 \mathrm{~m}$, but were not so dense as at locality $\mathrm{C}$. Hematite is always present in the joints and pitchblende may occur in one of the joints (1600 ur).

Thorium-dominated mineral occurrences were found both as small joint fillings and as radioactive dykes. The radioactive joints are located in the vicinity of the carbonatitic volcanics around Qagssiarssuk. The joints strike mainly $60^{\circ}$, and the radioactivity can be traced 1.5 to $10 \mathrm{~m}$. Carbonate and pyrite, sometimes with fluorite and hematite, are associated with these joints.

Several types of radioactive dyke occur in the area, and they all trend about $60^{\circ}$. The width is $3-5 \mathrm{~m}$ and they can be traced for more than $10 \mathrm{~km}$. The most common type is a weakly radioactive (55 ur) red trachyte dyke. Three other types of more radioactive (400500 ur) dyke are found. The most common type is a brown, fine- to medium-grained dyke. Another is a green, aegirine-rich, medium- to coarse-grained dyke, which may be found along the same trend as the brown dyke. The third type is a fine-grained, dark brown microsyenite. The dykes cut both sandstone and granite, which are strongly altered in a 1-2 m zone from the contact. The red sandstone is either bleached or green and the granite may be red or green with aegirine. The contacts of the green and brown dykes are sheared, and flow structures occur in the dyke. At one locality the bedding in the sandstone has been bent upward. The dykes are cut by quartz veins.

The unconformity between the granitic peneplane and the Eriksfjord Formation was prospected. It is normally very badly exposed due to talus. At several localities a weak radioactivity is found associated with black layers of heavy minerals about $0.5-1 \mathrm{~m}$ above the contact. The individual layers are up to $5 \mathrm{~cm}$ thick and are concentrated in a $1 \mathrm{~m}$ section. The radioactivity is caused mainly by thorium. At one locality the basal conglomerate showed a weak elevation in radioactivity, which is also due to thorium.

Detailed water sampling was carried out in the prospected area to test the usefulness of the method in this area with considerable vegetation. In total 200 samples from lakes and 
streams were collected. The analytical results show anomalous high content of uranium in both types of water sample. These high values are in the western half of the area where uranium mineral occurrences are also found (fig. 25, loc. B \& C). The pitchblende occurrence in the sandstone wedge (fig. 25, loc. A) is not reflected in the results of the water sampling because of the drainage pattern around that locality.

Stream-water samples from the Eriksfjord Formation in the southern part of the area and along the coast of Tunugdliarfik give high values $(0.5-0.9 \mathrm{ppb} \mathrm{U})$ compared with samples from other parts of the Formation $(0.00-0.15 \mathrm{ppb} \mathrm{U})$. The area is clearly anomalously high in uranium, and in the small area prospected by ground scintillometry uranium occurrences were found in joints.

\section{Preliminary conclusions}

Uranium mineral occurrences continue to be found in the Granite Zone (fig. 20) and they are limited in size, although a rather dense distribution of thin, uraniferous joints within a 50 $\times 10 \mathrm{~m}$ zone was found at one locality. Small $1.5 \mathrm{~m}$ long pitchblende veins and smears were found in the Julianehåb granite west of Qagssiarssuk, where the granite is dissected by many fractures.

Uranium mineral occurrences were also found in the sandstones of the Eriksfjord Formation. The uranium mineral occurrences are located in joints below the contact to the basalt sill which seems to have acted as a barrier for the hydrothermal fluids. Pitchblende smears are also found scattered in a zone over $1 \mathrm{~km}$ in a brecciated sandstone wedge between two major faults.

The sandstone/granite contact was prospected, but no unconformity-type uranium mineral occurrences were located in the contact itself although the uranium mineral occurrences found in the granite at locality $\mathrm{C}$ (fig. 25) lie very close to the unconformity.

All the uranium mineral occurrences found in the prospected area are associated with joints and fractures, and they mostly follow the $60^{\circ}$ tension direction. The area is rather poorly exposed, and new uranium occurrences may therefore be localized by further prospecting using other methods.

Thorium mineral occurrences are found both in joints and as radioactive dykes. These joints seems to be associated spatially with the carbonatitic rock around Qagssiarssuk. The radioactive dykes have previously been associated with the central complexes (Hansen, 1968).

The results of the water sampling identified areas with anomalous uranium, and whenever these were prospected uranium mineral occurrences were found. Both stream and lake water samples seem therefore to be useful in prospecting for uranium in this area. Water samples taken in parts of the Eriksfjord Formation are anomalously high in uranium, which justifies a future detailed water sampling programme in this area followed by ground scintillometry.

\section{References}

Allaart, J. H. 1983: Descriptive text to Geological map of Greenland 1: 100 000, Narssarssuaq 61 V.3 Syd. 20 pp. Copenhagen: Grønlands geol. Unders. 
Armour-Brown, A., Tukiainen, T. \& Wallin, B. 1982: The South Greenland uranium exploration programme. Final Report of reconnaissance results. Unpubl. intern. GGU rep., 95 pp.

Armour-Brown, A., Tukiainen, T., Wallin, B., Bradshaw, C. \& Emeleus, C. H. 1983: Uranium exploration in South Greenland. Rapp. Grønlands geol. Unders. 115, 68-75.

Armour-Brown, A., Tukiainen, T., Nyegaard, P. \& Wallin, B. 1984: The South Greenland regional uranium exploration programme. Final report of progress 1980-1983. Unpubl. intern. GGU rep., 107 pp.

Emeleus, C. H. \& Upton B. G. J. 1976: The Gardar period in southern Greenland. In Escher, A. \& Watt, W. S. (edit.) Geology of Greenland, 154-181. Copenhagen: Geol. Surv. Greenland.

Emeleus, C. H. \& Stephenson, D. 1970: Field work between Tunugdliarfik and Tasiussaq. Rapp. Grønlands geol. Unders: 28, 30-32.

Hansen, J. 1968: A study of radioactive veins containing rare-earth minerals in the area surrounding the Ilimaussaq alkaline intrusion in South Greenland. Bull. Grønlands geol. Unders. 76 (also Meddr Grønland 181,8) $47 \mathrm{pp}$.

Poulsen, V. 1964: The sandstones of the Precambrian Eriksfjord Formation in South Greenland. Rapp. Gronlands geol. Unders. 2, $16 \mathrm{pp}$.

Van Breemen, O., Aftalion, M. \& Allaart, J. H. 1974: Isotopic and geochronologic studies on granites from the Ketilidian mobile belt of South Greenland. Bull. geol. Soc. Amer. 85, 403-412.

\section{Geophysical field work in relation to mineral exploration programmes in South Greenland}

\section{Thorning and M. Boserup}

Geophysical field work in connection with mineral exploration programmes was carried out in two areas in South Greenland: on the Narssaq peninsula south-west of Qagssiarssuk in co-operation with P. Nyegaard and A. Armour-Brown (Sydex project), and north of Motzfeldt Sø in co-operation with T. Tukiainen (Niobium project). This note briefly describes the objectives of the field work and gives examples of the data acquired from one area.

The field activities were supported logistically from GGU's facilities in Narssarssuaq (J. Lau), and were carried out from tent camps in the two areas. Camps were moved by S-61 helicopter. Besides the authors, Egon Hansen (electronics technician) and Jette Halskov (assistant) participated in the field work which took place from June 27th to August 27th. The summer was characterized by frequent bad weather including storms and snow and, consequently, data coverage is not as complete as had been hoped. The main objectives of the field work, however, were achieved.

There were several innovations in this summer's instrumentation (see later) and equipment. The use of two new tents (Hansen Weatherport, insulated) for the mess and 'geophysical' huts made it possible to endure the hardships of long periods of bad weather and to make the geophysical equipment usable in sub-zero temperatures, fog and other types of adverse weather. These gains easily outbalance the slightly added total weight of the camp. 